\title{
PEMANFAATAN ASAP CAIR ALANG-ALANG (Imperata cylindrica) SEBAGAI PENGAWET TERHADAP KARAKTERISTIK BUAH PISANG MAKAU (Musa spp.)
}

\author{
Dian Fitriarni*, Rafika Ayuni \\ Jurusan Teknologi Pertanian, Politeknik Negeri Ketapang \\ Penulis korespondensi: greenice712@gmail.com
}

\begin{abstract}
Research on the utilization of liquid smoke especially for preservation of fruit has been done and become one of alternative methods that can be used to maintain fruit shelf life. Liquid smoke raw materials can come from a variety of sources one of which comes from the Alang-alang (Imperata cylindrica). This study aims to determine the ability of liquid smoke made from alang-alang as a preservative of bananas and to know the effect on the characteristics of bananas. The sample used in this research is a local banana known as Pisang Makau (Musa spp). This research uses experimental method with 7 days of storage time. Initial stages of the research are cleaning the fruit, dyeing, drying, and storage at room temperature. This research uses liquid smoke from alang-alang by using 2 various concentrations 50\% and 100\%. The next stage is the analysis of the characteristics of bananas such as color, fruit texture, fruit weight, sugar content, and vitamin $C$ levels. Based on the analysis results obtained by Pisang Makau with the treatment of liquid has a longer shelf life than the control. Based on the results of the analysis of the shelf life of fruit treated with liquid smoke decreased levels of sugar and vitamin C levels. Percentage decrease levels of sugar and vitamin $C$ between the fruit with the treatment and control not much different. This shows that liquid smoke from alang-alang has the ability to retain the shelf life of bananas without affecting sugar and vitamin C levels in bananas in this case for Pisang Makau. Levels of sugar and vitamin $C$ in bananas decreased during the process of storage and bunding of fruit.
\end{abstract}

Keywords: Liquid smoke, Alang-alang, Perservation, Pisang Makau

\section{PENDAHULUAN}

Pisang dalam Bahasa Inggris "banana" termasuk famili musaceae merupakan salah satu buah segar yang populer di seluruh dunia. Tanaman pisang banyak tersebar di wilayah tropis maupun subtropis seperti Indonesia, Malaysia, Asia, wilayah Australia yang beriklim tropis yang terdiri dari berbagai macam varietas, ukuran, bentuk, dan warna yang beragam. Buah pisang merupakan buah yang sangat digemari di Indonesia. Berdasarkan Angka Tetap (ATAP) tahun 2013 pisang mencapai produksi 6.28 juta ton. Sebanyak $50 \%$ pisang dipasok dari Indonesia sehingga Indonesia merupakan negara penghasil pisang terbesar di Asia. Tingginya produksi pisang di Indonesia karena iklim yang sesuai sehingga hampir seluruh wilayah Indonesia merupakan daerah penghasil pisang. Sebanyak $90 \%$ produksi pisang masih digunakan untuk konsumsi dalam negeri, sedangkan untuk ekspor hanya 10\% (Suhartanto et al., 2008). Produksi pisang di Indonesia mengalami peningkatan dalam kurun waktu 5 tahun terakhir. Tercatat pada tahun 2011 jumlah produksi pisang mencapai $6,132,685$ ton, tahun 2012 tercatat $6,189,046$ ton, tahun 2013 mencapai $6,279,279$ ton, tahun 2014 mencapai $6,862,559$ ton, tahun 2015 menjadi $7,299,266$ ton. Berdasarkan hasil proyeksi, 
produksi pisang di Indonesia selama periode 2016-2020 diproyeksikan naik sebesar $1.98 \%$ per tahun, meskipun setiap tahunnya mengalami penurunan laju pertumbuhan produksi terhadap pisang. Kenaikan produksi pisang tertinggi diprediksi akan terjadi pada tahun 2017 sebesar 2.04\% (Pusat Data \& Sistem Informasi Pertanian Kementerian Pertanian, 2016)

Pisang memiliki potensi besar khususnya di dalam negeri. Suhartanto et al. (2012) sebanyak 90\% produksi pisang Indonesia oleh pasar dalam negeri. Hal ini merupakan salah satu peluang yang masih cukup lebar khususnya di bidang pariwisata. Berkembangnya pariwisata di Indonesia dan bertambahnya wisatawan asing yang datang ke Indonesia menjadikan peluang pasar buah pisang semakin meningkat. Distribusi pisang di Indonesia terutama untuk konsumsi hotelhotel berbintang dan pasar swalayan yang membutuhkan pisang dengan kualitas yang tinggi. Keluhan yang datang dari pengusaha hotel-hotel berbintang adalah belum ada suplier yang menyediakan buahbuahan salah satunya adalah pisang dengan kualitas yang tinggi.

Berdasarkan komposisi kimia, buah pisang merupakan buah yang memiliki kadar air yang relatif tinggi. Pisang segar matang mengandung kadar air 75-77\% (Abano \& Sam, 2011; Holcroft, 2015; Chauhan \& Jethva, 2016). Buah pisang mentah memiliki kadar air $73.47 \%$, ketika matang kadar air mencapai $77.19 \%$, dan kemudian meningkat saat buah pisang lewat matang $79.22 \%$ (Adeyemi \& Oladiji, 2009). Berdasarkan persentase kadar air buah pisang tersebut maka buah pisang dikategorikan buah yang cepat mengalami kerusakan. Kadar air merupakan salah satu faktor yang mempengaruhi kerusakan buah (Rawat, 2015). Kadar air yang tinggi mengakibatkan buah pisang sangat mudah mengalami kontaminasi mikroorganisme yang dapat mengakibatkan kerusakan buah.

Buah pisang merupakan buah
klimakterik yaitu buah yang tetap
mengalami proses pematangan setelah pemanenan. Buah klimakterik menghasilkan cukup etilen untuk membuat perubahan biokimia pada buah sehingga menghasilkan perubahan warna, tekstur, aroma dan komposisi kimia. Marriot et al. (1981) menyatakan fase klimakterik ditandai dengan peningkatan produksi etilen, konsumsi oksigen lebih tinggi, konversi pati menjadi gula sederhana, degradasi klorofil, dan relokasi nutrisi mikro dan makro antara pulp dan bagian tanaman lainnya. Berdasarkan hal itu, dapat terlihat bahwa salah satu kendala dalam distribusi dan penjualan pisang adalah umur simpan buah pisang yang singkat.

Berbagai metode telah dilakukan untuk mempertahankan umur simpan pisang, salah satunya adalah menggunakan asap cair. Beberapa penelitian terdahulu telah melaporkan penggunakan asap cair untuk mempertahankan umur simpan buah, seperti pada buah pisang Ambon Curup (Silsilia et al., 2011); buah tomat (Utaminingtyas, 2015). Asap cair merupakan produk yang dihasilkan dari proses pirolisis bahan nabati (tumbuhan) yang pemanfaatannya sangat luas mulai dari pemanfaatannya sebagai bioflavor, pembentuk warna, pengawet produk pangan, biopestisida, tambahan pupuk cair, pengawet kayu, juga untuk proses penggumpalan lateks. Banyaknya manfaat asap cair ini disebabkan karena kandungan senyawa fenol, karbonil, dan asam yang dimilikinya (Darmadji, 2009). Salah satu asap cair yang dapat digunakan adalah asap cair alang-alang. Fitriarni dan Prawiro (2017) melaporkan bahwa asap cair dari alang-alang memiliki kemampuan sebagai antifungi terhadap Aspergilus sp. 
Tujuan penelitian ini adalah untuk menguji kemampuan asap cair alang-alang dalam mempertahankan umur simpan buah pisang. Sampel yang digunakan dalam penelitian ini adalah komoditas pisang lokal yang ada di Kabupaten Ketapang yang dikenal dengan nama pisang makau (Musa ssp.). Pisang ini memiliki potensi sebagai alternatif bahan baku produk olahan pisang di Ketapang. Secara umum di Ketapang pisang ini banyak digemari oleh masyarakat Ketapang dan banyak dikonsumsi dalam bentuk buah segar maupun dalam bentuk produk olahan pisang seperti jejumput dan salai pisang. Selain itu pisang ini dapat menjadi salah satu komoditas buah khas daerah yang perlu dilestarikan agar dapat menjadi salah satu ciri khas daerah yang dapat menunjang perkembangan sektor pariwisata sehingga berdampak pada meningkatnya pendapatan masyarakat.

\section{METODE}

Alat yang digunakan dalam penelitian ini adalah alat evaporator, gelas ukur, erlenmeyer, gelas beker, alumunium foil, nampan, timbangan, wrapping, hot plate, spatula, kain saring, penetrometer, carter, botol kaca, kertas label, timbangan analitik terbuka, jangka sorong, refraktometer, pipet tetes, tabung reaksi, dan corong. Bahan yang digunakan dalam penelitian ini adalah pisang makau, asap cair dengan konsentrasi $100 \%$ dan $50 \%$, air mineral, iodium $\left(\mathrm{I}_{2}\right)$.

Metode penelitian mengadopsi metode kerja Silsilia et al. (2015) dengan modifikasi. Pisang makau yang dijadikan sampel adalah pisang makau yang diambil dari tanaman rakyat yang ditanam di daerah Kecamatan Benua Kayong, Kabupaten Ketapang, Kalimantan Barat. Sebanyak 3 tandan pisang diambil yang dipilih berdasarkan kondisi fisik pisang dalam keadaan baik dan tidak terluka. Sebanyak 5 sisir pisang diambil dari setiap tandan dan dipilih dengan kriteria matang pisang no 5 berdasarkan Alves et al. (1999) dalam Cabrera-Padilla et al. (2014). Buah pisang yang telah dipilih dilap dengan air bersih yang telah disterilkan terlebih dahulu. Setelah dibersihkan kemudian dicelupkan dalam asap cair masing-masing $50 \%$ dan $100 \%$ selama kurang lebih 10 menit. Buah pisang yang telah dikeringkan kemudian ditempatkan pada nampan pada suhu kamar. Untuk mengetahui hasil, dilakukan pengamatan dilakukan setiap 3 hari dan dihentikan pada saat buah pisang makau pada setiap perlakuan telah rusak. Parameter pengamatan dilakukan terhadap warna, berat, dan tekstur buah. Analisa kimia dilakukan dengan parameter jumlah gula dan kadar vitamin $\mathrm{C}$.

\section{HASIL DAN PEMBAHASAN}

Pisang makau merupakan salah satu komoditas pisang yang ada di Kabupaten Ketapang, Kalimantan Barat. Sebutan pisang makau merupakan nama daerah yang diperuntukkan bagi pisang ini karena pisang ini merupakan pisang khas yang telah umum dikonsumsi oleh masyarakat di daerah Kabupaten Ketapang. Sejauh penelusuran hingga saat ini secara teoritis belum didapatkan referensi yang melaporkan terkait pisang makau. Namun, diketahui berdasarkan pengamatan di lapangan pisang ini merupakan buah pisang yang dapat dikonsumsi sehingga dapat dimasukkan dalam golongan eumusa atau pisang yang dapat dikonsumsi langsung ataupun dalam bentuk olahan pisang. Pisang ini termasuk kelompok pisang M. Parasidaca var Sapientum (Musa sp. AA Group) yang termasuk kelompok pisang yang dapat dimakan langsung. Berdasarkan pengamatan visual pisang makau memiliki kesamaan bentuk buah dengan pisang susu dan pisang mas. Berdasarkan pengamatan terhadap karakteristik morfologi buah, kulit buah pisang makau berwarna kuning ketika buah masak, jumlah buah persisir 14-16 buah, panjang buah 12-14 cm, diameter buah 3.5- 
$4.2 \mathrm{~cm}$, ujung buah meruncing, potongan buah melintang bulat, rasa dominan pada buah saat masak adalah manis agak asam, dan sedikit sepat.

Salah satu parameter pengamatan untuk menilai karakteristik pisang selama penyimpanan adalah warna buah pisang. Pengamatan terhadap warna buah pisang mangacu pada skala warna kulit buah pisang dari Alves et al. (1999) dalam Cabrera-Padilla et al. (2014) (Gambar 1). Hasil pengamatan terhadap warna buah dimasukkan dalam tabel hasil pengamatan (Tabel 1). Berdasarkan Tabel 1 dan Gambar 1 hasil pengamatan buah secara visual didapatkan terjadinya perubahan kondisi kulit buah pisang makau selama penyimpanan.

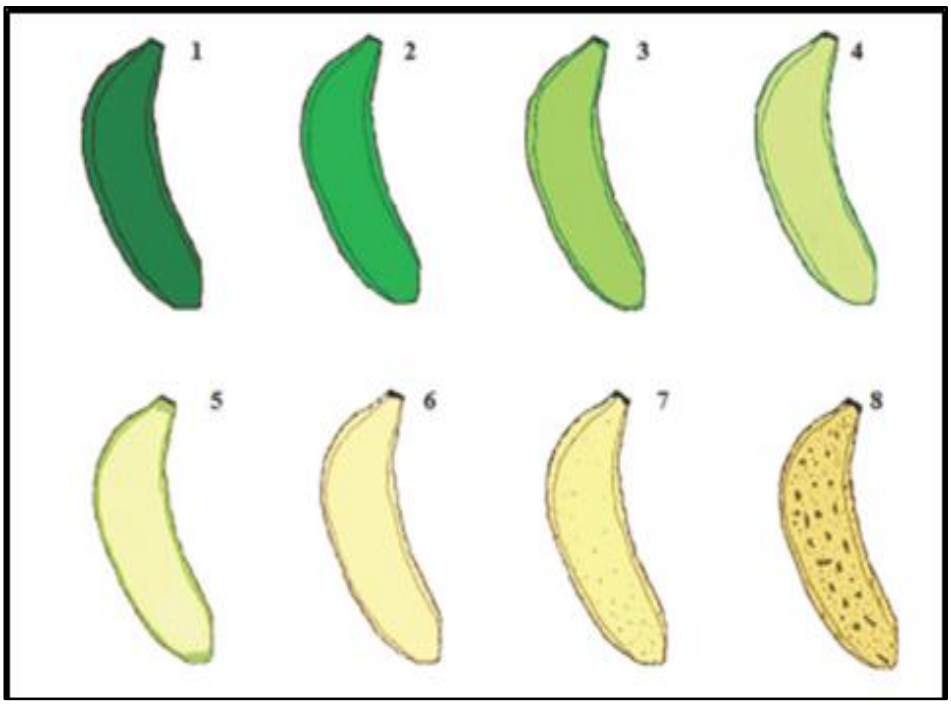

Gambar 1. Skala perubahan warna kulit buah pisang. 1. Hijau; 2. Hijau sedikit kuning; 3. Warna hijau dominan dari warna kuning; 4. Warna kuning dominan dari warna hijau; 5. Kuning dengan ujung buah berwarna hijau; 6. Kuning keseluruhan; 7. Kuning tua dengan bintik-bintik coklat kecil; 8. Kuning dengan area berwarna coklat yang lebih besar (Alves et al., (1999) dalam Cabrera-Padilla et al., (2014))

Tabel 1. Hasil Pengamatan Buah Secara Visual

\begin{tabular}{cccc}
\hline Hari & Kontrol & P50\% & P100\% \\
\hline 0 & 5 & 5 & 5 \\
3 & 6 & 6 & 6 \\
5 & 7 & 6 & 6 \\
7 & $*$ & 7 & 8 \\
\hline
\end{tabular}

Keterangan : *(buah telah rusak)

Berdasarkan Gambar 2 dapat terlihat perbedaan kondisi buah dari tiap perlakuan. Pada perlakuan kontrol buah pisang memiliki lama waktu penyimpanan hanya 3 hari, pada hari ke 5 buah pisang telah rusak dan sedikit berair, sehingga pengamatan dihentikan. Pada perlakuan pemberian asap cair alang-alang 50\% didapatkan umur simpan buah dapat bertahan hingga hari ke 7 proses pengamatan. Walaupun pada hari ke 7 kulit buah mulai dipenuhi oleh bintik-bintik coklat yang lebar akan tetapi tekstur daging buah masih keras walaupun tidak sekeras tekstur buah pada hari pertama penyimpanan. Buah pisang dari perlakuan 
ini rusak pada umur simpan 12 hari. Pada perlakuan pemberian asap cair alang-alang $100 \%$ didapatkan buah pisang dapat bertahan selama 5 hari, namun pada hari ke lima kulit buah pisang mulai dipenuhi dengan bintik-bintik coklat yang semakin melebar hingga pengamatan pada hari ke 7 . Berdasarkan pengamatan pada hari yang sama, tekstur buah dari perlakuan $100 \%$ asap cair alang-alang pada hari ke 7 lebih keras dibandingkan buah kontrol. Buah pisang dari perlakuan ini rusak pada umur simpan 10 hari.

Berdasarkan hasil di atas dapat disimpulkan perlakuan terbaik adalah pemberian asap cair dengan konsentrasi 50\%. Pemberian asap cair 50\% lebih efektif mempertahankan sifat fisik buah pisang seperti warna dan tekstur dibandingkan dengan kontrol dan perlakuan $100 \%$. Karakteristik buah dari perlakuan 50\% mampu mempertahankan buah pisang hingga hari ke 7 proses pengamatan. Walaupun kulit buah telah tampak rusak akan tetapi tekstur buah masih keras jika dibandingkan dengan kontrol.

Secara teoritis perubahan warna kulit pisang terjadi karena degradasi klorofil. Degradasi klorofil terjadi secara bertahap yang diawali dengan munculnya pigmen berwarna kuning atau pigmen karotenoid yang ada pada kulit pisang. Selain karotenoid, kulit pisang juga mengandung senyawa fenol, sehingga ketika buah mulai masuk pada fase penuaan, terjadi akumulasi etilen. Senyawa fenolik pada kulit pisang teroksidasi oleh enzim polifenoloksidasi yang mengakibatkan timbulnya bercak atau bintik-bintik hitam yang terus berkembang hingga menutupi buah. Von loesecke (1929) selama pematangan buah klorofil menurun menjadi nol. Gross et al. (1976) pada kulit pisang matang ditemukan alpha karoten, beta karoten dan lutein. Palmer (1971) kulit pisang kaya akan senyawa fenolik, yang kemudian teroksidasi oleh enzim polifenoloksidase.

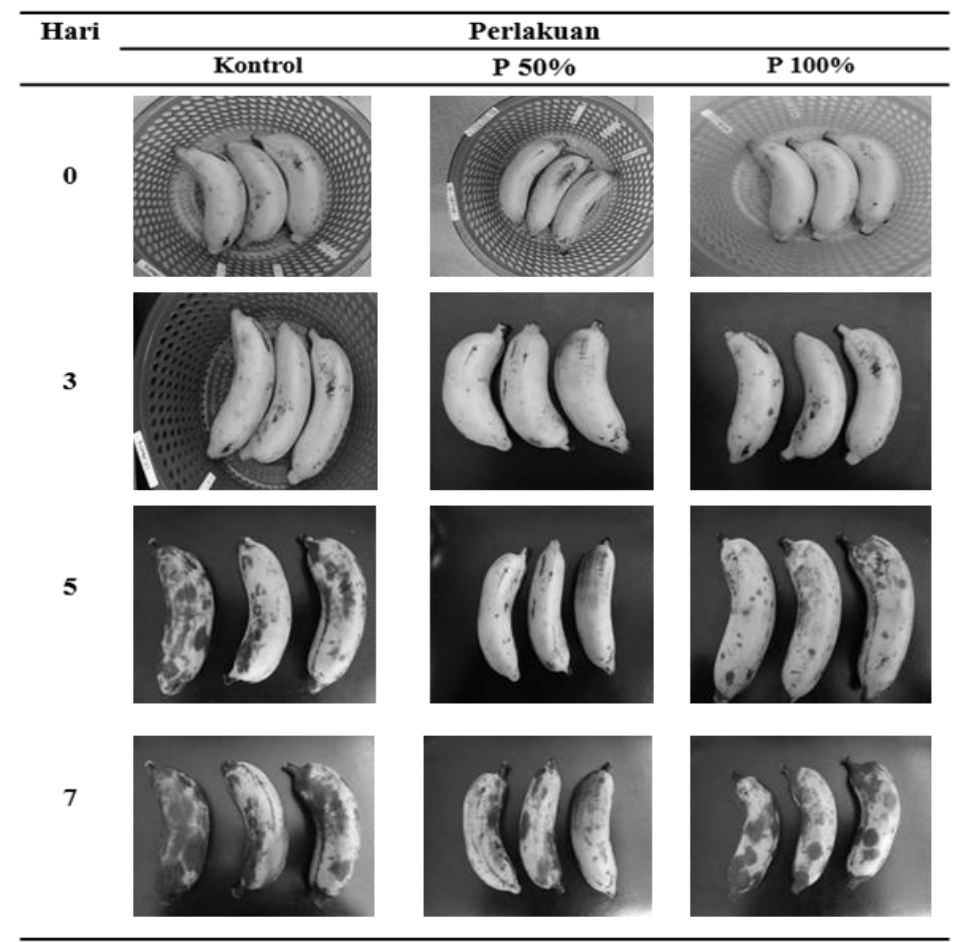

Gambar 2. Perubahan Buah Pisang Selama Penyimpanan 


\section{Berat Buah}

Berat buah yang diperoleh oleh pisang kontrol pada awal pengamatan memiliki berat berkisaran $100.68 \mathrm{gr}$ dan pada hari 7 memiliki berat berkisaran 88.39 gr, pada pisang sebelum diberi perlakuan asap cair $50 \%$ memiliki berat awal 98.27 gr dan berat akhir $91.04 \mathrm{gr}$, pisang perlakuan asap cair $100 \%$ memiliki berat awal 100.77 gr dan berat akhir 92.41 gr. Hasil pengukuran dibuat dalam bentuk grafik dan disajikan dalam Gambar 3.

Secara alami berat pisang umumnya akan menurun karena faktor lamanya penyimpanan. Penyimpanan pisang pada suhu kamar memicu terjadinya reaksi biokimia dalam buah pisang. Reaksi biokimia akan terus meningkat dengan semakin meningkatnya suhu. Proses biokimia ini membutuhkan energi. Oleh karena itu, pati dalam daging pisang diubah menjadi gula dan digunakan sebagai sumber energi sel. Kelebihan energi yang dihasilkan dari proses respirasi buah dibebaskan dari jaringan buah melalui proses transpirasi. Proses transpirasi ini mengakibatkan penurunan berat buah pisang selama penyimpanan. Siriboon dan Banlusilp (2004) menyatakan bahwa proses biokimia buah memerlukan energi yang diperoleh dari proses respirasi. Kelebihan energi dari proses respirasi keluar dari jaringan melalui proses transpirasi. Kandungan air yang keluar dari buah mengakibatkan buah kehilangan beratnya. Wills et al. (1981) menyatakan bahwa pada proses pematangan laju respirasi meningkat mengakibatkan susut bobot.Winarno, (2002) dalam Murtadha et al.( 2012) respirasi pada buah klimaterik umumnya sama yaitu akan mengalami peningkatan $\mathrm{CO}_{2}$ yang mendadak pada saat pematangan, kemudian pada saat kemasakan dari tanaman menjelang sempurna, dan telah lewatnya kemasakan, maka aktivitas respirasi akan semakin menurun.

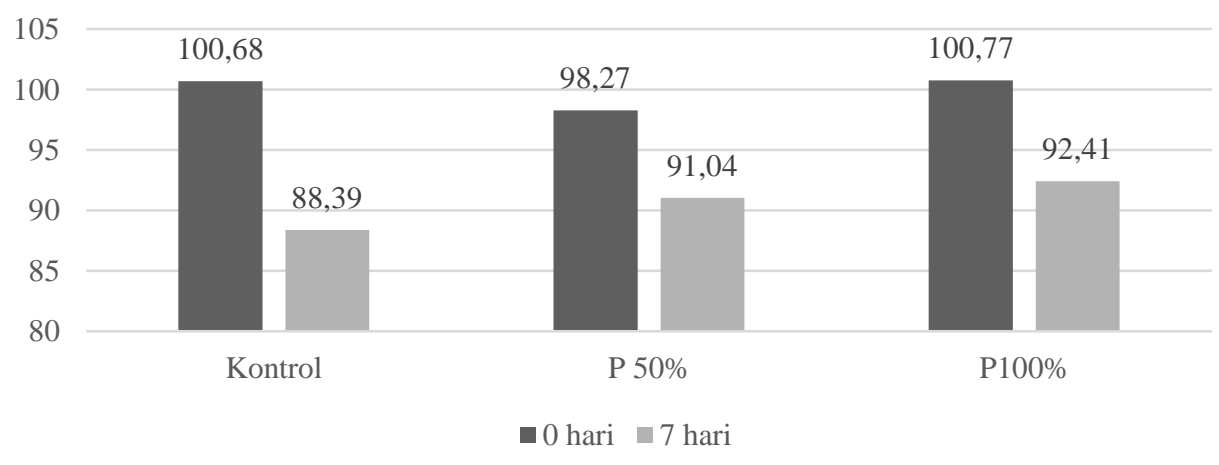

Gambar 3. Grafik Berat Buah Pisang Makau pada Hari 1 dan Hari 7

\section{Vitamin C}

Pengukuran kadar vitamin C dilakukan berdasarkan metode Chem Fax (2016) dan Daniel (2017). Metode yang digunakan merupakan metode kualitatif yang disertai perhitungan kasar kadar vitamin C $(\mathrm{mg} / 100 \mathrm{~mL})$. Tujuan pemakaian metode ini adalah untuk mengetahui kadar vitamin $\mathrm{C}$ kasar yang terkandung dalam buah pisang yang telah melalui perlakuan kemudian membandingkannya dengan standar kadar vitamin $\mathrm{C}$ pada buah pisang segar yang telah diketahui. Berdasarkan hasil pengukuran diperoleh kadar vitamin $\mathrm{C}$ dalam satuan mg dalam $100 \mathrm{mg}$ vitamin $\mathrm{C}$. Pisang kontrol bertambah dari $39.7 \mathrm{mg} / 100$ $\mathrm{mL}$ menjadi $2.90 \mathrm{mg} / 100 \mathrm{~mL}$ pisang sebelum dengan perlakuan asap cair $50 \%$ bertambah dari $37.66 \mathrm{mg} / 100 \mathrm{~mL}$ menjadi 
$44.41 \mathrm{mg} / 100 \mathrm{~mL}$, pisang dengan perlakuan asap cair $100 \%$ bertambah dari $49,1 \mathrm{mg} / 100 \mathrm{~mL}$ menjadi $41.4 \mathrm{mg} / 100 \mathrm{~mL}$ (Gambar 4).

Berdasarkan grafik pada Gambar 4 diketahui terjadi penurunan kadar vitamin C pada buah pisang selama proses penyimpanan. Kadar vitamin $\mathrm{C}$ buah pisang makau pada tahap awal lebih kecil jika dibandingkan hasil pengukuran vitamin $\mathrm{C}$ dari pisang mas Kirana yaitu berkisar pada $72.2-86.2$ (mg/100 g bahan) (Yulyana, 2015) dan vitamin C pisang nangka yang menggunakan perlakuan etilen $0,5 \%$ sebanyak $74.56 \mathrm{mg} / 100 \mathrm{~g}$ (Pande et al. 2017). Secara umum, berdasarkan hasil tersebut dapat disimpulkan penggunaan asap cair berpotensi mempertahankan sifat kimia buah khususnya dalam hal ini vitamin $\mathrm{C}$. Persentase penurunan kadar vitamin $\mathrm{C}$ terbesar diperoleh dari perlakuan kontrol, penurunan kadar vitamin $\mathrm{C}$ juga terlihat dari pisang dengan perlakukan asap cair $100 \%$. Hal ini dapat disebabkan pisang dengan perlakuan asap cair alang-alang $100 \%$ telah melewati fase klimakterik sehingga kandungan vitamin $\mathrm{C}$ (asam askorbat) menurun. Berbeda dengan hasil pengukuran kadar vitamin $\mathrm{C}$ pada pisang dengan perlakuan $50 \%$ terjadi peningkatan. Sejalan dengan hasil pengamatan terhadap karakteristik fisik buah pisang (Tabel 1). Peningkatan kandungan vitamin $\mathrm{C}$ pada buah pisang dari perlakuan ini dapat terjadi dikarenakan buah pisang yang dianalisa pada hari 7 masih berada pada fase klimakterik sehingga kandungan vitamin C saat dianalisis memberikan hasil yang cenderung naik dibanding kadar vitamin $\mathrm{C}$ pada awal perlakuan. Selama proses pemasakkan buah, khususnya dalam hal ini buah pisang, kandungan vitamin $\mathrm{C}$ pada buah pisang akan berkurang karena adanya aktivitas enzim ascorbic acid oxidase. Enzim ini mengoksidasi asam askorbat menjadi asam dehidroaskorbat dalam kondisi aerobik. Proses ini akan menghasilkan produk dalam bentuk padatan terlarut.

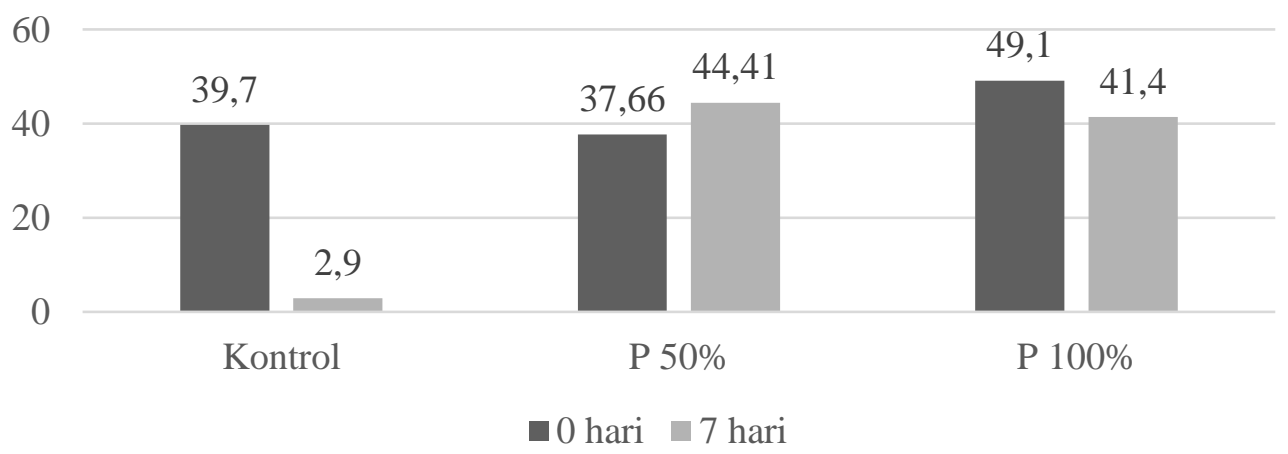

Gambar 4. Grafik Kadar Vitamin C Pisang Makau pada hari 1 dan hari 7 (mg/100 mL

Askorbat oksidase diketahui sebagai enzim utama yang bertanggung jawab pada degradasi vitamin C. Kadar vitamin C dalam pisang dapat naik dan turun dikarenakan banyak faktor. Kandungan vitamin $\mathrm{C}$ pada pisang turun selama proses pematangan (Lee \& Kader 2000). Meningkatnya kandungan asam organik selama proses pematangan buah pisang sebagai hasil dari proses dekarboksilasi asam oksalat oleh enzim oksalat oksidase (Shimokawa et al., 1972). Salah satu asam organik yang dihasilkan paling banyak dan meningkat selama proses pematangan buah pisang adalah asam malat (Wyman \& Palmer, 1963).Vitamin C dalam buah pisang ambon meningkat karena kadar air buah yang tinggi (Wenkam, 1990). Asam askorbat meningkat selama proses pematangan, hingga level tinggi saat buah 
pisang matang penuh dan menjadi menurun ketika buah pisang terlewat matang (Will, 1983). Buah pisang dengan tingkat kematangan $85-90 \%$ yang diberi bahan pemacu pematangan etilen memiliki nilai total padatan terlarut, total asam dan vitamin $\mathrm{C}$ yang tertinggi (Murtadha et al., 2012).

\section{Kadar Gula}

Pengukuran kadar gula menggunakan refraktormeter dalam skala ${ }^{\circ}$ brix yang sama dengan berat gram sukrosa per $100 \mathrm{~g}$ dari larutan sukrosa. Berdasarkan hasil pengukuran diperoleh kadar gula pisang kontrol berkurang dari 8 obrix menjadi 19 brix, pisang sebelum dengan perlakuan asap cair $50 \%$ berkurang dari $4{ }^{\circ}$ brix menjadi 5 brix dan pisang dengan perlakuan $100 \%$ berkurang dari $7{ }^{\circ}$ brix menjadi $6{ }^{\circ}$ brix (Gambar 5).

Pemberian asap cair mampu mempertahankan umur simpan buah pisang sehingga mempengaruhi perubahan kandungan gula pada buah. Umumnya semakin lama waktu penyimpanan maka semakin tinggi kadar gula, karena terjadi pemecahan pati menjadi menjadi gula sederhana. Namun perbedaan terjadi pada hasil pengukuran kadar gula reduksi pada P 100\%. Pisang yang diperlakukan dengan pemberian asap cair $100 \%$ mengalami penurunan kadar gula reduksi. Hal ini mungkin disebabkan karena penggunaan asap cair murni memberikan efek memperlambat proses reaksi pemasakan sehingga dapat menekan jalan laju respirasi buah pisang mengakibatkan proses perombakkan pati menjadi karbohidrat sederhana cenderung berjalan lebih lambat dibanding dua perlakuan lainnya. Poland $e t$ al. (1938) proses biokimia selama proses pematangan adalah proses konversi pati. Kandungan pati yang terkandung dalam daging buah pisang dikonversi menjadi gula sederhana melalui proses enzimatis. Golongan gula sederhana yang ditemukan adalah glukosa, fruktosa, sukrosa dan maltosa dalam jumlah yang kecil.

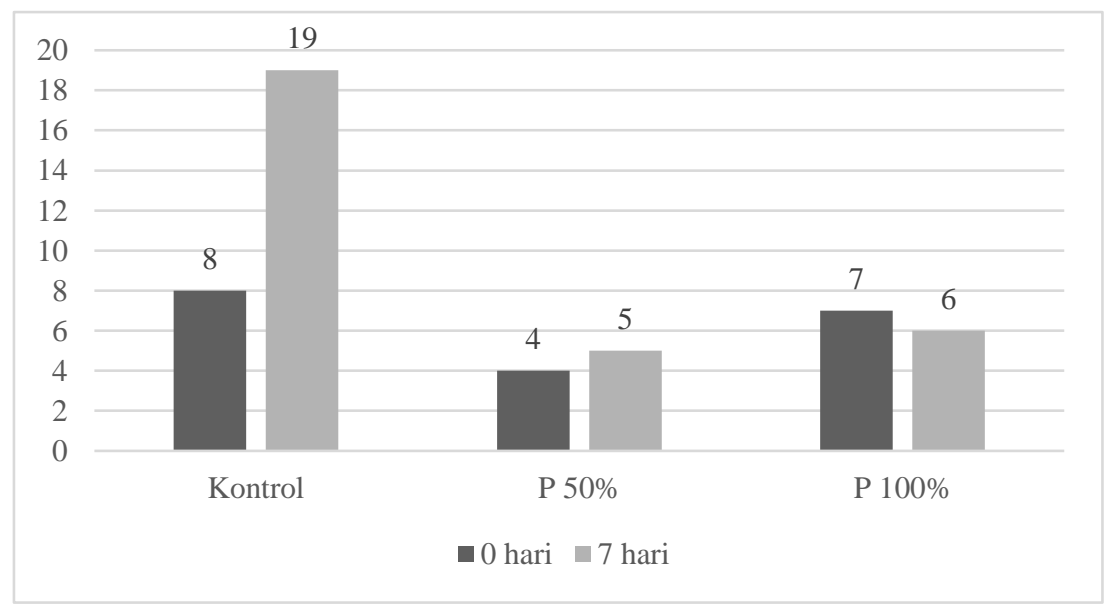

Gambar 5. Grafik Kadar Gula Pisang Makau pada Hari 1 dan Hari 7 ( ${ }^{\circ}$ Brix)

Perubahan kadar gula reduksi pada buah pisang terjadi karena proses biokimia yang terjadi pada buah pisang. Pemberian asap cair alang-alang memperpanjang umur simpan dan menunda proses biokimia yang terjadi. Asap cair merupakan kondesat hasil pirolisis tumbuhan. Perbedaan bahan baku dan metode yang digunakan untuk menghasilkan asap cair akan memberikan perbedaan pada komposisi kimia asap cair. Kemampuan asap cair untuk mempertahankan mutu bahan pangan, khususnya dalam penelitian ini buah pisang makau karena beberapa senyawa yang terkandung dalam asap cair yang 
memiliki potensi sebagai antimikrobia. Lingbeck et al. (2014) dalam produk hasil pirolisis terdapat senyawa fenol, karbonil dan asam organik yang mampu memberikan perubahan karakteristik bahan pangan pada flavor, warna, dan sebagai antimikrobia. Kemampuan ini menjadikan asap cair salah satu bahan antimikrobia alami yang dapat digunakan untuk pengawetan bahan pangan.

Masing-masing senyawa dalam asap cair memiliki mekanisme kerja sendirisendiri. Fenol bekerja merusak membran sitoplasma sehingga mengakibatkan cairan intraseluler dalam sel keluar. Karbonil merupakan senyawa toksik bagi mikrobia, bekerja dengan mekanisme menghambat pertumbuhan mikrobia dengan menghambat pembentukkan dinding sel dan menginaktifkan enzim membran sitoplasma. Asam organik dalam asap cair menghambat dalam bentuk tidak terdisosiasi. Bentuk yang tidak terdisosiasi ini menjadikan senyawa asam organik dalam asap cair mudah masuk ke dalam sel mikrobia yang kemudian mengubah $\mathrm{pH}$ internal sel. Asam organik yang telah berada dalam sel terdisosiasi melepaskan proton. Pelepasan proton memicu sel untuk menggunakan energi cadangan dan meningkatkan produksi ATP untuk mengeluarkan proton. Hal ini terus berlangsung hingga menghambat proses metabolisme sel yang penting untuk mempertahankan kehidupan sel.

Budijanto et al. (2008) melaporkan hasil analisis GC-MS menunjukkan terdapat 40 komponen yang teridentifikasi dari asap cair, dengan 7 komponen yang dominan yaitu 2-Methoxyphenol (guaiacol), 3,4-Dimethoxyphenol, Phenol, 2-methoxy-4-methylphenol, 4-Ethyl-2methoxyphenol, 3-Methylphenol, dan 5Methyl-1,2,3-trimethoxybenzene. Selain itu, tidak ditemukan adanya senyawasenyawa Policyclic Aromatic Hydrocarbon (PAH) yang bersifat karsinogenik termasuk benzo[a]pyrene dalam asap cair tempurung kelapa. Berdasarkan Peraturan Pemerintah RI No.74 Tahun 2001, asap cair tempurung kelapa dengan nilai LD50 lebih besar dari $15.000 \mathrm{mg} / \mathrm{kg}$, maka termasuk bahan yang tidak toksik dan aman digunakan untuk produk pangan.

\section{KESIMPULAN DAN SARAN}

Pemberian asap cair berpengaruh terhadap karakteristik fisik dan kimia pisang makau selama proses penyimpanan. Pisang dengan perlakuan asap cair memiliki umur simpan yang lebih lama yaitu $7-12$ hari dibandingkan dengan pisang kontrol yang hanya bertahan selama 3 hari. Buah pisang kontrol mengalami kerusakan secara spontan dimana perubahan warna kulit diikuti dengan perubahan tekstur. Berbeda dengan buah yang diberi perlakuan asap cair. Perubahan pada warna kulit buah tidak spontan diikuti dengan perubahan tekstur buah. Tekstur buah masih keras walaupun kulit buah telah rusak. Perbedaan konsentrasi asap cair yang diberikan juga mempengaruhi kandungan kimia buah. Pisang P 50\% mengalami kenaikan gula reduksi dan vitamin $\mathrm{C}$. Hal ini berbeda dengan hasil pisang $\mathrm{P} 100 \%$ yang justru mengalami penurunan. Semakin tinggi asap cair maka proses pematangan buah semakin lambat. Lambatnya proses pematangan buah memberikan efek pada lambatnya proses biokimia yang terjadi dalam buah sehingga mempengaruhi kadar gula reduksi dan kadar vitamin $\mathrm{C}$ buah pisang.

\section{DAFTAR PUSTAKA}

Abano E. E. and Sam-Amoah. 2011. Effects Of Different Pretreatments On Drying Characteristics Of Banana Slices. ARPN Journal of Engineering and Applied cSciences. L. 6(11) :1819-6608.

Adeyemi, O. S., and Oladiji, A. T., 2009. Compositional changes in banana (Musa ssp.) fruits during ripening. 
African Journal of Biotechnology. 8 (5): 858-859.

Budijanto, S., Hasbullah, R., Prabawati, S., Setyadjit, Sukarno, Zuraida, I. 2008. Identifikasi dan Uji Keamanan Asap Cair Tempurung Kelapa Untuk Produk Pangan. J. Pascapanen. 5(1):32-40.

Badan Pusat Statistik. 2015. Statistik Tanaman Buah-Buahan dan Sayuran Tahunan (Statistical of Annual Fruit and Vegetable Plants). https: // media .neliti. com/ media/ publications/ 48342- ID - statistiktanaman-buahbuahan-dan-sayurantahunan-indonesia-2015.pdf.

Diakses tanggal 19 Januari 2018.

Cabrerapadilla, R Y., Oladeinde, T O., Finzer, J R D, Limaverde, J R. 2014. Drying of banana paste in rotatory dryer with inert bed Secagem de pasta de banana em secador rotativo com recheio de inertes. Braz. Jurnal . Food Technol. Campinas. 17(1):4150.

Chauhan, N and Jethva KR. 2016. Drying Characteristics of Banana Powder. Indian Journal of Science. 23(77):75-88.

Chem Fax, 2016. Vitamin $C$ Testing. Publication No. 91358061616. https://www.flinnsci.com/globalasse ts/flinn-scientific/all-freepdfs/dc91358.pdf. Diakses Tanggal 10 Nopember 2017.

Darmadji, P. 2009. Teknologi Asap Cair dan Aplikasinya pada Pangan dan Hasil Pertanian. Pidato Pengukuhan Jabatan Guru Besar dalam Bidang Teknologi Pangan dan Hasil Pertanian. Fakultas Teknologi Pertanian. Universitas Gadjah Mada, Yogyakarta

Fitriarni, D., dan Prawiro, IS. 2017. Pemanfaatan Tanaman Alang-Alang (Imperata cylindrica (L.), Beauv.) Sebagai Bahan Baku Pembuatan
Asap Cair, Karakterisasi Sifat Fisik Dan Kimiawi Serta Uji Aktivitas Antifungi Secara In Vitro. Prosiding Seminar Nasional Hasil Penelitian (SNHP)-VII. Lembaga Penelitian dan Pengabdian Kepada Masyarakat. Universitas PGRI Semarang.

Gross, J.; Carmon, M; Lifshitz, A.; and Costes, C. 1976. Carotenoids of banana pulp, peel and leaves. $F d$. Sci. \& Tech. 9:211-14.

Holcroft, D. 2015. Water relations in harvested fresh produce. PEF White Paper No. 15-01. The Postharvest Education Foundation (PEF). http://www.postharvest.org/Water\% 20relations \%20PEF\%20white\%20p aper\%20FINAL\%20MAY\%202015. pdf. Diakses Tanggal 30 Januari 2018.

Lee, S.K., and Kader, A.A., 2000. Preharvest and postharvest factors influencing vitamin $\mathrm{C}$ content of horticultural crops. Postharvest Biology and Technology 20, 207220.

Lingbeck, JM., Cordero, P., O’Bryan, CA., Johnson, MG., Ricke, SC., Crandall., PG. 2014. Functionally of Liquid Smoke as an all-Natural Antimicrobial in Food Presevervation. Abstract. Meat Sci. 97(2):197-206.

Marriott, J., Robinson, M. and Karikari, S.K. Starch and sugar transformation during the ripening of plantains and bananas. Journal of the Science of Food and Agriculture, 32 (10), 10211026, 1981

Mahajan, B.V.C, Singh G, dan Dhatt A.S.,2008. Studies on ripening behaviour and quality of winter guava with ethylene gas ethephon treatments. Journal. Food Sci. Technol., 45: 81-84.

Murtadha, Elisa Julianti , Ismed Suhaidi.2012. Pengaruh Jenis 
Pemacu Pematangan Terhadap Mutu Buah Pisang Barangan (Musa paradisiaca L.). Jurnal.Rekayasa Pangan dan Pert., I (1)

Nair,S. dan Z. Singh, 2003. Pre-storage ethrel dip reduces chilling injury, enhances respiration rate, ethylene production and improves fruit quality of „Kensington ${ }^{\text {ee }}$ mango. Food, Agriculture \& Environment.1(2) : 93-97

Palmer, J.K. 1971. The Banana. In: The Biochemistry of Fruits and Their Products. A.C. Hulme, Ed. Academic Press, London

Pande, NPHD., Defiani, MR., dan Arpiwi, NL. 2017. Kandungan Gula Tereduksi dan Vitamin C dalam Buah Pisang Nangka (Musa parasidiaca forma typica) Setelah Pemeramam Dengan Ethrel dan Daun Tanaman. Jurnal Simbiosis. 5(2):64-68

Poland, G. L., Manion, J.L., Brenner, M. W., and Harris, P.L. 1983. Sugar Changes in the Banana during Ripening. Ind. Eng. Chem. 30(3):340-342.

Silsia, Devi and Yessy, Rosalina and Firman, Muda. 2011. Pemanfaatan Asap Cair Untuk Mempertahankan Kesegaran Buah Pisang Ambon Curup. Agro Industri. 1 (1). pp. 8-16. ISSN 2088-5369

Rawat, S. 2015. Food Spoilage: Microorganisms and their prevention. Asian Journal of Plant Science and Research. 5(4):47-56

Seymour, G, B. 1993. Banana, In G. B. Seymour, J, E, Taylor and G. A. Tucker (eds) Biochemistry of Fruit Ripening, Chapter 3. Chapman \& Hall. London. 83-106.

Seymour GB, Thompson AK, John P. Inhibition of degreening in the peel of bananas ripened at tropical temperatures. Annals of applied biology. 1987; 110(1):145-51.

Shimokawa, K., Ueda, Y., and Kasai, Z. 1972. Dearboxylation of Oxalic Acid during Ripening of Banana Fruit (Musa sapientum L.). Agr. Biol. Chem. 36(11): 2021-2024.

Siriboon, N. And Banlusilp. 2004. A Study in the Ripening Process of 'Namwa' Banana. AU Journal of Technology. 159-164.

Suhartanto, R. Sobir, Harti, H. 2012. Teknologi Sehat Budidaya Pisang. Pusat Kajian Hortikultura Tropika, LPPM-IPB. Bogor. ISBN 978-97918361-3-5.

Suhartanto, M.R., Harti, H. dan Haryadi, S.S. 2008. Program Pengembangan Pisang. http://pkht.or.id/ . Diakses 30 Januari 2018

Pusat Data dan Sistem Informasi Pertanian Sekretariat Jenderal Kementrian Pertanian. 2014. Outlook Komoditi Pisang. http://pusdatin.setjen.pertanian.go.id . Diakses tanggal 30 Januari 2018

Utaminingtyas. 2015. Pengaruh penambahan asap cair tempurung kelapa (Grade 1 dan grade 2) Terhadap Pertumbuhan Kapang dan Sifat Organoleptis Tomat (Lycopersicon esculentum M) selama masa simpan. Skripsi. http://digilib.uinsuka.ac.id/15710/1/BAB\%20I\%2C\% 20V\%2C\%20DAFTAR\%20PUSTAK A.pdf. Diakses Tanggal 26 Agustus 2018

Wenkam, N. S. 1990. Food of Hawaii and the Pacific basin, fruits and fruit products: Raw, processed, and prepared. Journal of Hawaii Agricultural Experiment Station Research and Extension Series 4: 96110 
Wills, R. B. H., Lim, J. S. K. and Greenfield, H. 1983. Changes in chemical composition of 'Cavendish' banana (Musa acuminata) during ripening. Journal of Food Biochemistry 8: 69- 77

Wills, R.H., T.H. Lee, D. Graham, Mc. Gkasson, W.B. Hall, 1981. Postharvest, An Introduction to The Physiology and Handling of Fruits and Vegetables. New South Wales University Press, Kensington, Australia

Wyman, H and Palmer, J.K. 1963. Organic Acids in The Ripening Banana Fruit. www.planphysiol.org. Diakses tanggal 18 Janurari 2018.

Von Loesecke, H.W. 1929. Quantitative changes in the chloroplast pigments in the peel of bananas during ripening. J. Amer. Chem. Soc. 15:2439-43.

Yulyana, E. 2105. Kriteria Kematangan Pascapanen Pisang Mas Kirana (Musa sp. AA Group) Berbasis Satuan Panas. Skripsi. Fakultas Pertanian. Institute Pertanian Bogor. Bogor. 